\title{
NORMATYWNOŚĆ USYTUOWANA. UJĘCIE EKOLOGICZNE
}

\begin{abstract}
Streszczenie. W artykule rozważa się, na ile normatywność jest usytuowana w ludzkich ekosystemach biologicznych i kulturowych, z naciskiem na rolę artefaktów. Podstawowe pytanie dotyczy tego, czy afordancje - różnie konceptualizowane - mogą mieć charakter normatywny. Tekst krótko wprowadza do ekologii poznawczej oraz psychologii ekologicznej, po czym przedstawia możliwość zastosowania klasycznej teorii afordancji do normatywności wraz z krytyką, a następnie - próbę modyfikacji tego ujęcia przez odwołanie się do afordancji społecznych i kulturowych. Przegląd ten i płynące z niego wnioski uzupełniono oryginalną propozycją wzbogacenia badań nad normatywnością afordancji o analizę ich struktur oraz roli projektowania interakcji człowiek-artefakt.
\end{abstract}

Słowa kluczowe: norma, afordancja, poznanie, percepcja, ekologia, kultura, artefakt

1. Wprowadzenie. 2. Afordancje jako normy. 3. Ekologia relacji społecznych. 4. Normatywność a inżynieria poznawcza. 5. Podsumowanie.

\section{WPROWADZENIE}

Czy nasz ludzki świat jest normatywny? Z perspektywy konsekwentnego eksternalizmu poznawczego pytanie to można potraktować niemal dosłownie: odnosiłoby się wówczas do normatywnego charakteru pewnych własności relacyjnych otoczenia podmiotu. Takie ujęcie norm pojawiło się w kontekście interdyscyplinarnych badań nad poznaniem. W niniejszej pracy przyglądam się praktykom normatywnym z perspektywy ekologii poznawczej (przedstawię ją poniżej), nie wdając się w rozstrzyganie natury norm ani tego, jak należy je uzasadniać.

Przyjmuję bardzo podstawowe rozumienie norm społecznych - do których się tutaj ograniczam za prezentowanymi autorami - opierając się na wstępnej definicji norm społecznych Stanfordzkiej Encyklopedii 
Filozofi $i^{1}$ oraz odnosząc do przytaczanych tutaj prac poświęconych ekologicznemu ujęciu normatywności ${ }^{2}$. Normy społeczne to zwyczajowe zasady, które regulują zachowanie jednostek i grup w danym społeczeństwie. Działający podmiot, jeśli ma działać normatywnie, musi mieć możliwość zachowania niezgodnego z normą. Do norm społecznych należy co najmniej większość norm moralnych. Natomiast "praktyką normatywną" nazywam działanie podjęte $\mathrm{z}$ uwagi na jakąś normę społeczną - przy czym mam tutaj na myśli zarówno działania służące realizacji tej normy, jak i uniknięciu jej (czego nie należy zrównywać z działaniami neutralnymi wobec norm).

Po tej krótkiej charakterystyce przechodzę do rozważenia, czy i w jaki sposób normatywność jest osadzona poznawczo w danym otoczeniu, rozumianym jako kompleks fizyczno-biologiczno-kulturowy. Optymalną ramą teoretyczną dla badania relacji między normatywnością a usytuowaniem poznania wydaje się ekologia poznawcza. Jej ogólnym celem jest badanie zjawisk poznawczych w kontekście danych kultur, $\mathrm{z}$ naciskiem na system zależności między poznaniem a strukturami wspólnot. Antropolog kognitywny Edwin Hutchins podaje trzy ujęcia historycznie ważne dla ekologii poznawczej, gdzie obok ekologii umysłu Gregory'ego Batesona i kulturowo-historycznej teorii czynności Lwa Wygotskiego istotne miejsce zajmuje psychologia ekologiczna Jamesa Gibsona wraz z teorią afordancji ${ }^{3}$. Hutchins w ramach ekologii poznawczej wskazuje na potrzebę redefinicji kultury. Proponuje, by traktować ją nie jak zbiór materialnych i abstrakcyjnych artefaktów, lecz jako proces adaptacyjny (przebiegający tak wewnątrz, jak i na zewnątrz jednostkowych

1 C. Bicchieri, R. Muldoon, Social Norms, w: Stanford Encyclopedia of Philosophy (2011), https://plato.stanford.edu (dostęp: 17.03.2017).

2 M. Heras-Escribano, M. de Pinedo, Are affordances normative?, Phenomenology and the Cognitive Sciences (2016)15, 565-589; P. Lo Presti, An ecological approach to normativity, Adaptive Behavior 24(2016)1, 3-17; E. Rietveld, J. Kiverstein, A rich landscape of affordances, Ecological Psychology 26(2014)4, 325-352.

3 E. Hutchins, Cognitive Ecology, Topics in Cognitive Science 2(2010)4, 707-712. 
umysłów), obejmujący również procesy poznawcze. Samo myślenie jest również rodzajem praktyki kulturowej, nabywanej i doskonalonej przez współuczestniczenie, w ramach danych ekosystemów kulturowych ${ }^{4}$. Ogólnie biorąc, wszelkie ludzkie praktyki są możliwe oraz sensowne w ramach kulturowych nisz ekologicznych, w których nawarstwiły się różnorodne sfery funkcjonowania człowieka. Takie postrzeganie problematyki kulturowej zaadoptował zapoczątkowany przez Gibsona kierunek, który nie tylko wykazuje do dziś żywotność, ale też nadal jest rozwijany i modyfikowany na potrzeby różnych zadań badawczych.

Należy w końcu postawić pytanie: po co stosować teorię poznania, a dokładniej - percepcji do badań nad normatywnością? Czy nie jest to cokolwiek sztuczny zabieg, którego efekty mogą prowadzić do nieuprawnionych konkluzji?

Odpowiedź może zabrzmieć paradoksalnie: propozycja Gibsona i kontynuatorów bardziej stanowi pewną teorię praktyk ludzkich niż teorię percepcji, tak jak tę ostatnią rozumie klasyczny nurt badań nad poznaniem. To właśnie traktowanie jej jako teorii percepcji konkurencyjnej wobec zastanych, w oderwaniu od konceptualnego kontekstu, jest nieporozumieniem. Wynika to z zupełnie innej mapy problemów badawczych, do której odnosi się koncepcja Gibsona; dyskutowana poza nią, budzi nadmierne kontrowersje. Jak stwierdza Alan Costall, ,koncepcja afordancji stanowi punkt graniczny w »podejściu ekologicznym« u Gibsona, który odchodzi od teorii percepcji w stronę pełniejszej ekologii podmiotu działającego"s. Ekologia ta przenosi akcent $\mathrm{z}$ pytania o to, w co jesteśmy wyposażeni, by poznawać świat, na pytanie o nasze związki poznawcze ze światem i uformowaną z nich strukturę. Twórca psychologii ekologicznej

4 E. Hutchins, Cognition in the wild, Cambridge 1995, 353-355; E. Hutchins, The cultural ecosystem of human cognition, Philosophical Psychology 27(2014)1, 34-49.

5 A. Costall, Afordancje kanoniczne w kontekście, tłum. z ang. K. Bielecka, Avant 3(2012)2, 299. 
podważa tradycyjny dualizm podmiotu i otoczenia, ujmując je relacyjnie, a nie opozycyjnie - co widoczne jest od początku do końca w jego głównej pracy.

Propozycję Gibsona określano jako atak na zakładane „ubóstwo rzeczywistości"'. Z jej perspektywy podmiot nie jest zdany na otwartą przestrzeń pełną neutralnych danych, lecz zawsze funkcjonuje w świecie ustrukturyzowanym, w określonym systemie fizycznym, biologicznym i kulturowym, korzystając z gotowych wzmocnień, wskazówek i rozwiązań. Dzieje się tak dzięki afordancjom. Anglojęzyczny termin affordance utworzono od czasownika to afford, oznaczającego między innymi „umożliwiać”, „oferować”, „dostarczać”, „podsuwać”. Powstały na tej podstawie neologizm określa pewne własności relacyjne (lub po prostu relacje) elementów otoczenia danego podmiotu, które skłaniają go do określonego zachowania, niejako „oferując się" ze swoją poręcznością czy przydatnością: kamień może posłużyć jako młotek, duży kamień - zastąpić krzesło, a krzesło - służyć nie tylko do siedzenia, ale też na przykład do wybicia okna. Jak zaznacza Gibson, nie należy przywiązywać wielkiej wagi do statusu ontologicznego afordancji, gdyż istotny jest nie sposób ich istnienia, tylko fakt naszego dostępu do stosownych informacji obecnych w otaczającym świetle ${ }^{8}$. Afordancje postrzegamy niezależnie od zmian w oświetleniu i perspektywie, wykorzystując je w działaniu. Pojmowanie owego postrzegania elementów otoczenia jako postrzegania bezpośredniego, jak i Gibsonowski antyreprezentacjonizm stanowić mogą źródło kontrowersji. Natomiast teza niezwykle istotna tak dla psychologii ekologicznej, jak i dla nas tutaj, brzmi: struktury naszego otoczenia są dla nas znaczące, nieobojętne pod względem wartości, a wręcz w nie bogate (value-rich). Afordancje

6 J. Gibson, The Ecological Approach to Visual Perception, New York 2014.

7 Zob. A. Costall, dz. cyt., 297.

8 Gibson zajmował się percepcją wzrokową i związanym z nią typem afordancji, należy jednak pamiętać również o innych modalnościach. 
są tym, co dane otoczenie umożliwia bądź oferuje podmiotowi dla jego pożytku lub dla szkody9.

Koncepcja Gibsona, poza wspomnianymi wcześniej kontrowersjami, wykazuje pewne niedopowiedzenia i ograniczenia, między innymi dotyczące odniesień do społeczeństwa i kultury: wbrew niektórym deklaracjom badacza w tym względzie, zwierzęta i ludzi potraktowano głównie jako obserwatorów, a relacja afordancyjna ogranicza się do niezależnej kulturowo diady podmiot ${ }^{10}$-przedmiot. Skądinąd jednak wpłynęła i wpływa do dziś na dużą grupę badaczy i teoretyków ${ }^{11} . Z$ drugiej strony pojęcie afordancji funkcjonuje równolegle i w dużej mierze niezależnie w rozległej dziedzinie dizajnu ${ }^{12}$, do czego jeszcze wrócimy.

\section{AFORDANCJE JAKO NORMY}

Zagadnienie normatywności afordancji podjął filozof i psycholog ekologiczny Anthony Chemero. W jego ujęciu afordancje - rozumiane jako relacje między naszymi zdolnościami czy kompetencjami a właściwościami otoczenia - są normatywne. Normatywność jest przez nie niejako przejmowana $\mathrm{z}$ kompetencji podmiotu, również relacyjnych, od których ma być nieodłączna ${ }^{13}$. Z perspektywy klasycznej literatury dotyczącej normatywności można wytykać Chemero nadmierne uproszczenia czy wręcz niekonsekwencje - co jednak

9 J. Gibson, dz. cyt., 127, 140 i dalej.

10 „Agent” jako odpowiednik anglojęzycznego agent budzi zastrzeżenia, dlatego posługuję się określeniem „podmiot działający” lub po prostu „podmiot”.

11 D. Dotov i in., Zrozumieć afordancje, tłum. z ang. D. Lubiszewski, N. Strehlau, Avant 3(2012)2, 282-295.

12 Zdecydowałem się na określenie „dizajn”, ponieważ alternatywne „wzornictwo” nie wydaje się odpowiednie na określenie projektowania interakcji między odbiorcą a produktem filmowym, muzycznym, multimedialnym itp. - a również i takie wchodzą w zakres dziedziny określanej w języku angielskim mianem design (zob. prace D. Normana wymienione w wykazie bibliograficznym niniejszej pracy).

13 A. Chemero, Radical embodied cognitive science, Cambridge 2009, 145, 218. 
również komplikuje sama natura pojęcia. Dlatego też warto przyjrzeć się bardziej rozbudowanej krytyce Chemerowskiej koncepcji normatywności afordancji, której podjęli się Manuel Heras-Escribano i Manuel de Pinedo ${ }^{14}$, jako że naświetla ona pewne charakterystyczne tropy podobnych klasycznych ujęć.

Wymienieni autorzy wytaczają trzy argumenty przeciwko jego koncepcji, a ponadto próbują osłabić wage jego teorii afordancji jako relacji. Pierwszy argument to zarzut ekwiwokacji w odniesieniu do błędu percepcyjnego i błędu działania. Chemero opisuje afordancje jako relacje między podmiotem a otoczeniem, jednak w sposób nieuprawniony łączy możliwość popełnienia błędu percepcyjnego z możliwością niewłaściwego działania. Tymczasem „błędne postrzeganie” znaczy tyle, co „brak informacji”, a nie „błąd” w tradycyjnym sensie tego słowa. Na przykład ktoś dostrzega lub nie dostrzega afordancji „przechadzalności” (walkability), czyli możliwości przejścia po czymś do tego zdatnym (jak kładka nad wodą lub zwalony konar drzewa mogący za taką kładkę posłużyć), a równocześnie może nieskutecznie czy wadliwie $z$ niej skorzystać. To wiedzie nas do drugiego zarzutu Heras-Escribano i de Pinedo: niektórzy ortodoksyjni teoretycy psychologii ekologicznej wskazują na symetryczną relację determinacji między informacją $w$ otoczeniu a percepcją: jedna ściśle determinuje drugą, a w konsekwencji błąd percepcyjny staje się niemożliwy (wspomniany już brak informacji nie jest błędem ze strony podmiotu). Tym samym nieporozumienie możliwe jest wyłącznie $\mathrm{w}$ zakresie działania, a nie percepcji. Natomiast trzeci zarzut Heras-Escribano i de Pinedo opiera się na Wittgensteinowskim argumencie przeciwko możliwości ustalania i stosowania się do norm prywatnych przez podmiot działający nie-społecznie. Chemerowska relacja między podmiotem a otoczeniem jako wyizolowana diada nie przystaje do

14 M. Heras-Escribano, M. de Pinedo, dz. cyt., 578-586. 
idei praktyk normatywnych jako praktyk społecznych, tak jak chcą je rozumieć nasi autorzy ${ }^{15}$.

Mimo wszystko Heras-Escribano i de Pinedo nie wykluczają związków afordancji z normatywnością. Nadzieje pokładają właśnie w społecznym charakterze praktyk normatywnych, czego nie rozwija koncepcja Chemero. Normy są zapośredniczone społecznie, co pozwala na zastosowanie kryterium poprawności - konieczne dla oceny danego działania. I w tym kontekście można również postrzegać niektóre afordancje, a więc w relacji do praktyk społecznych, co zupełnie nie pokrywa się z tezą, że afordancje przejmują normatywny charakter $z$ umiejętności. Wykorzystywanie pewnych afordancji można więc oceniać jako właściwe lub niewłaściwe w odniesieniu do zewnętrznego tutaj kontekstu społecznego, a nie dlatego, że stanowi to szczególną cechę w relacji afordancyjnej, jak chciałby Chemero ${ }^{16}$.

Jednak przeciwstawianie Chemerowskiego rozumienia afordancji jako relacji w podejściu Gibsona oraz innych, rzekomo ortodoksyjnych, badaczy nie wydaje się uprawnione. Pionierska koncepcja Gibsona została wyrażona w sposób niekiedy dość zagmatwany bądź niedopracowany. Niemniej podkreślał on dwubiegunowość czy dwukierunkowość afordancji, odniesionej do środowiska i równocześnie do podmiotu ${ }^{17}$. Z kolei powoływanie się na pogląd Michaela Turveya jest nietrafione: badacz ten (wraz z innymi) w pewnym stopniu sprzeniewierzył się idei Gibsona i psychologii ekologicznej, ograniczając pojęcie afordancji do właściwości środowiska przy jednoczesnym wprowadzeniu kategorii efektywności, właściwej z kolei podmiotowi percepcij ${ }^{18}$.

Zastrzeżenia budzą również próby wykluczenia błędu percepcyjnego z powodu symetrycznej relacji między informacją w otoczeniu

15 Tamże, 578-586.

16 Tamże, 586-587.

17 Np. J. Gibson, dz. cyt., 129.

18 Np. M. Turvey, Affordances and prospective control: An outline of the ontology, Ecological Psychology 4(1992), 173-187. 
a percepcją. Być może wspomniana zasada symetrii mogłaby odnosić się do nieskomplikowanych relacji diadycznych w nieskonfliktowanym poznawczo otoczeniu i najlepiej dla niezbyt wysoko zorganizowanego zwierzęcia. Tymczasem trudno mówić o takich dopasowanych diadach typu zamek-klucz, skoro w realnych sytuacjach mamy do czynienia ze zróżnicowaniem jakości percepcji afordancji, uzależnionej chociażby od cielesnego skalowania informacji, co wykazywał już William Warren i inni ${ }^{19}$, jak i $\mathrm{z}$ afordancjami różnego stopnia czy jakości (jak w przypadku różnie, a nie zawsze optymalnie zaprojektowanych schodów lepiej i gorzej oferujących „wchadzalność”, ścian skalnych w różnym stopniu oferujących „wspinalność” itd.). Ponadto owe realne sytuacje przynoszą złożone i nielinearnie zorganizowane „pakiety” afordancji - co analizował William Gaver (będzie o nich jeszcze mowa poniżej); warto też wziąć pod uwagę percepcyjny efekt, do jakiego prowadzi współwystępowanie afordancji kontradyktorycznych, wzajemnie się znoszących lub zniekształcających pierwotne ich postrzeganie ${ }^{20}$. Natomiast wnikliwego opisu wpływu kontekstu kulturowego na percepcję tych złożonych struktur podjął się Costall (do którego również powrócę). Praca Heras-Escribano i de Pinedo dostarcza krytyki Chemerowskiej koncepcji afordancji normatywnych, a także postulatu odniesienia normatywności do społecznego funkcjonowania niektórych afordancji; jednak realizacja pozostawia wiele do życzenia z uwagi na ogólnikowość i zupełny brak odwołań bibliograficznych.

19 Np. W. Warren, S. Wang, Visual guidance of walking through apertures, Journal of Experimental Psychology (1987)13, 371-383; W. Warren, Perceiving affordances: visual guidance of stair climbing, Journal of Experimental Psychology 10(1984)5, 683-703.

20 Analizę afordancji kontradyktorycznych („dysonansowych”) rozwijam w osobnym studium (Cognitive Engineering of Movie Making - w przygotowaniu). 


\section{EKOLOGIA RELACJI SPOŁECZNYCH}

Pracę niejako zarzuconą przez przytaczanych autorów podejmuje $\mathrm{Pa}$ trizio Lo Presti ${ }^{21}$, koncentrując się na osadzeniu normatywności w realnych, zmiennych sytuacjach. W tym świetle praktyki normatywne nie polegają na postępowaniu według bezwzględnie obowiązujących reguł, a te ostatnie pełnią funkcje pragmatyczne. Autor przywołuje tutaj Searle’owskie rozróżnienie między definiującymi regułami konstytutywnymi a regułami regulatywnymi, formującymi dane działanie z uwagi na kontekst i zamierzony cel. Przykładem tych drugich może być stosowanie się do normy zachowania odpowiedniego dystansu podczas rozmowy, czego uczymy się (zazwyczaj) od dziecka - należy tutaj brać pod uwagę różne kręgi kulturowe oraz różne struktury społeczne (na przykład pracownicze czy rodzinne), również zmieniając przestrzeń społeczno-kulturową, jak to się dzieje w przypadku imigrantów - i nabieramy wprawy, która nie bierze się z używania linijki czy uważnego skalowania własnego położenia względem innych, choć oczywiście zdarza nam się towarzyskie faux-pas, co zwykle szybko korygujemy. Tutaj nie uczymy się żadnych ścisłych reguł postępowania, by spełniać wymogi normy. Posiadana wiedza o tym, jak zachowywać się zgodnie z normami, może być „wiedzą z uczestnictwa” albo wiedzą objaśniającą, jak się zachowywać; w ramach naturalnych, spontanicznych praktyk społecznych nabywamy zwykle tę pierwszą. Ogólnie biorąc, formułowanie sądów jest wtórne wobec normatywności, reguły jako takie są zbyt statyczne, aby mogły stanowić jej obligatoryjną podstawę, a podążanie za nimi stanowi tylko szczególny typ zachowania normatywnego. W kontekście ślepego kierowania się regułą autorzy powołują się na analizowaną przez Wittgensteina sytuację, kiedy to trafiamy na "twardą skafę"22. Działanie na tym poziomie nadal

21 P. Lo Presti, dz. cyt.

22 „Moja motywacja się wyczerpała, natrafiłem na twardą skałę; moja łopata się wygięła. Jestem więc skłonny powiedzieć: »I takie też jest moje działanie«" (L. Wittgenstein, 
może być normatywne, choć niepojęciowe. Mimo iż nie możemy w żaden sposób uzasadnić, dlaczego robimy to, co robimy, i jesteśmy ślepo posłuszni samemu działaniu - to nie działamy przypadkowo czy bez sensu, bo nadal działamy odpowiedzialnie. Tę odpowiedzialność podtrzymują inni, z którymi dzielimy wspólne praktyki, techniki działania, zwyczaje, wszystko w podzielanym kontekście społecznym, spójnym i dynamicznym. Należy jednak pamiętać, że działanie „na twardej skale" nie jest normatywne, gdy odbywa się w izolacji od niszy społecznych praktyk ${ }^{23}$.

Wyraźmy to w terminologii psychologii ekologicznej: kontekst społeczny stanowiłby odpowiednio poszerzone pojęcie niszy ekologicznej, w której funkcjonuje dana społeczność i z którą związane są normy kierujące działaniem ludzi. Wymiar społeczny uwzględniał już sam Gibson, pisząc, że tym, co inne zwierzę oferuje obserwatorowi, jest nie tylko zachowanie, ale również interakcja społeczna. Afordancja taka angażuje parę (lub więcej) zwierząt w jedną pętlę współdziałania, niezależnie od rodzaju takiej interakcji: seksualnej, wspólpracy czy nawet rozmowy ${ }^{24}$. Lo Presti powtarza za Erikiem Rietveldem i Julianem Kiversteinem ${ }^{25}$, że to właśnie afordancje przydają niszy wymiaru normatywnego związanego z praktykami społecznymi. W ramach danej niszy jej „mieszkańcy” czy „użytkownicy” mają do czynienia nie $z$ dodaniem do zwykłego zachowania norm poprzez interpretację czy wnioskowanie, ale $z$ całym dynamicznym ich systemem. Normy są zrelatywizowane do danych nisz. Mało tego, zdaniem tych autorów stanowią rodzaj afordancji, umożliwiających bezpośrednie orientowanie się, jakie działania są właściwe. I chociaż afordancje takie nie są postrzegane bezpośrednio w sensie Gibsonow-

Philosophische Untersuchungen, I, § 217, Berlin 1984, tłum. z niem. B. Tarnas, cyt. za: D. Edmonds, J. Eidinow, Pogrzebacz Wittgensteina, tłum. z ang. L. Niedzielski, Warszawa 2002).

23 P. Lo Presti, dz. cyt., 3-14.

24 J.J. Gibson, dz. cyt., 41-42.

25 E. Rietveld, J. Kiverstein, dz. cyt., 325-352. 
skiej teorii percepcji, to ludzie uczą się bezpośredniego reagowania na nie w ramach danej niszy. Dużego znaczenia nabierają tutaj analizy Hefta dotyczące związków między funkcjonowaniem afordancji w wyższych (społecznych) strukturach ekologicznych a intencjonalnością ${ }^{26}$. Jednak pamiętać należy, że traktując (niektóre) afordancje społeczne jako normy, odnosimy je nie do izolowanego indywiduum, ale do (określonych) grup społecznych i dzielonych przez nie nisz. A jak pisze Costall i za nim Lo Presti, afordancje takie nie są mniej realne przez to, że są społeczne ${ }^{27}$.

Podsumujmy wnioski tego ostatniego: afordancje społeczne jako normy, odnoszące się do grup, a nie jednostek, są dynamiczne, zależne od kontekstu (czy raczej czułe na kontekst, by uniknąć skojarzeń z dowolnością), a więc zrelatywizowane do ekologicznych nisz społecznych, a przy tym negocjowalne, czyli nieusztywnione obowiązującymi niezależnie od sytuacji regułami konstytutywnymi. Kierowanie się regułami nie stanowi dla nich warunku sine qua non ${ }^{28}$. Wbrew autorowi, nie jestem skłonny traktować takiego podejścia jako jednoznacznego rozwinięcia koncepcji Gibsona, ten ostatni bowiem poświęcił zagadnieniu społecznego wymiaru relacji afordancyjnych raptem garść dość ogólnych uwag na niecałej stronie w swoim głównym dziele. Pewne wątpliwości dotyczą również prostego kwalifikowania niektórych afordancji społecznych jako norm; nadal pozostaje możliwość traktowania normatywności jako jedynie odnoszącej się do struktur otoczenia podsuwających określone działania.

Do możliwych „nośników” afordancji społecznych należy szerokie spektrum obiektów i ich konfiguracji. Mogą być nimi nasze ciała (wliczając wygląd, postawę, mimikę, gesty, modulację głosu), a także elementy otoczenia względnie nieprzetworzonego, jak i oczywiście

26 H. Heft, An ecological approach to psychology, Review of General Psychology 17(2013)2, 162-167.

27 P. Lo Presti, dz. cyt., 9.

28 P. Lo Presti, dz. cyt., 9-15. 
artefakty (od prostych przedmiotów codziennego użytku, przez mniej czy bardziej złożone urządzenia elektroniczne, po sieci komputerowe i przestrzenie wirtualne. Społecznie osadzona normatywność na ogół odnosiłaby się do różnorakich interakcji, zarówno międzyludzkich, jak i między człowiekiem czy grupą a nieosobowymi elementami otoczenia, przy czym kontakt może tu zachodzić zarówno bezpośrednio lub we wspólnej przestrzeni fizycznej, jak i zdalnie, za pomocą interfejsów itd. ${ }^{29}$.

Określenie „afordancje społeczne” wiąże się z pojęciem afordancji kulturowych; te ostatnie dotyczą możliwości działania z uwagi na określoną kulturową niszę ekologiczną, w której funkcjonują takie, a nie inne praktyki kulturowe. Afordancje te nie są czymś odciętym od „natury”: jak pokazuje Maxwell Ramstead i inni ${ }^{30}$, w ich obrębie można wyróżniać tak zwane naturalne oraz umowne afordancje kulturowe, gdzie pierwsze odnoszą się do artefaktów dostosowanych do ludzkiej biologii, na przykład utwardzonych dróg do dwunożności człowieka, drugie natomiast wiążą z kontekstem ludzkich zwyczajów, norm, ustaleń, organizacji pracy itd., jak to ma miejsce w przypadku sygnalizacji świetlnej. Oba rodzaje afordancji kulturowych są usytuowane w danych niszach społecznych i społecznie konstruowane. Kulturę należy tutaj postrzegać jako zakorzenioną w ludzkiej cielesności, co przystaje do podejścia Gibsona podkreślającego, że nie ma czegoś takiego jak „nowe” otoczenie, czy też otoczenie „sztuczne” w odróżnieniu od „naturalnego”, gdyż mamy do czynienia ciągle

29 Zob. np. F. Ferri i in., Social Requests and Social Affordances, PLoS ONE 6(2011)1, e15855, 1-9; M. Costantini, C. Sinigaglia, Grasping affordance, w: Joint attention: New developments, red. A. Seemann, Cambridge 2012, 431-459; J. Rączaszek-Leonardi i in., Young children's dialogical actions, IEEE Transactions on Autonomous Mental Development 5(2013)3, 210-221.

30 M. Ramstead, S. Veissière, L. Kirmayer, Cultural Affordances: Scaffolding Local Worlds Through Shared Intentionality and Regimes of Attention, Frontiers in Psychology 7(2016), art. 1090, 2. 
z tym samym otoczeniem przekształcanym przez człowieka - na tyle, na ile wpisuje się on w te zmiany własną biologią ${ }^{31}$.

Teza o kontekstowej i negocjacyjnej naturze normatywności znajduje pomocne rozwinięcie w analizach Costalla: $w$ jego ujęciu relacja afordancyjna nie jest ograniczona do pary podmiot-przedmiot; nie jest też binarna (dwuwartościowa), ponieważ może być stopniowalna, a więc optymalizowana względnie osłabiana czy neutralizowana - co pokazały już klasyczne badania Warrena ${ }^{32} \mathrm{i}$ innych. Istotne jest ujawnianie się nietypowych w danym kontekście afordancji (i zastosowań) danych obiektów, gdy jabłka można użyć jako pocisku, a pościeli do wykonania sznura służącego ucieczce. Tkwi za tym sieciowy charakter afordancji, uzależnionych od konkretnych konstelacji rzeczy, zdarzeń oraz towarzyszących im praktyk wiedzionych określonymi wartościami. Costall wskazuje na afordancje kanoniczne: normatywne sensy rzeczy w danym otoczeniu, szczególnie ludzkich artefaktów, odniesione do szerszych ram kulturowych. Afordancje nie są po prostu odkrywane ani nie stanowią umysłowej projekcji na pozbawione znaczenia elementy otoczenia. Afordancje są negocjowane; a oferowanie danemu podmiotowi danej afordancji stanowi efekt takich stopniowych, wypracowanych negocjacji ${ }^{33}$.

Przytoczone tu analizy i klasyfikacje, z jednej strony, wydają się komplikować obraz relacji między afordancjami a normatywnością; $z$ drugiej jednak dają większe pojęcie o architekturze poznania społecznego, wyczulonego na funkcjonujące w niej normy i przez nie kształtowanego. W znacznej liczbie przypadków traci sens poszukiwanie jednej, wyizolowanej relacji afordancyjnej dla jakiejś praktyki normatywnej, ponieważ odpowiada za nią względnie złożona

31 J. Gibson, dz. cyt., 129-130.

32 . H. Warren, Perceiving affordances, dz. cyt.

33 A. Costall, dz. cyt., 301-303. A. Costall, A. Richards, Canonical Affordances: The Psychology of Everyday Things, w: The Oxford Handbook of the Archaeology of the Contemporary World, red. P. Graves-Brown i in., Oxford 2013, 82-91. 
konstelacja komponentów materialnych i niematerialnych. Przyjrzyjmy się dwóm przykładom.

Gdy mamy do czynienia z ubiorem wyraźnie niezgodnym z normą - płciową, religijną, towarzyską, zawodową - to co właściwie składa się na reakcję innych uczestników danej praktyki normatywnej lub po prostu obserwatorów, kiedy komunikują swoje zgorszenie czy oburzenie? Nierzadko bowiem jest to reakcja dość emocjonalna, a nie zwykły sąd. W możliwym przypadku tego przykładu kobieta staje się obiektem zaczepek seksualnych ze strony niektórych mężczyzn tylko z uwagi na strój, uznany za prowokujący do określonych kontaktów. Mówiąc jednak o jakiejś normie rzekomo przyzwalającej i zmaterializowanej w odzieży, należy także pamiętać o potencjalnej normie powstrzymywania się od pewnych zachowań, niezależnie od domniemanej prowokacji. Można więc tutaj zapytywać, co takiego stało się kulturowo z naszą percepcją odzieży, że zamiast podsuwać po prostu zdatność do ogrzania, ochrony przed wilgocią czy słońcem, poszczególne ubrania oferują nam tak zwaną stosowność do sytuacji lub wręcz prowokują do pewnych działań.

Drugi przykład: spostrzegamy wózek z dzieckiem wciągany bądź zestawiany przez matkę $\mathrm{z}$ wysokich schodów lub drzwi pojazdu. Co powoduje, że tak różnie i bez zastanowienia reagujemy na ten widok? Jedni wykazują odruch rzucania się do pomocy, inni - do ucieczki (jeszcze inna grupa pozostaje obojętna). Czy to już kulturowa afordancja wózka, a właściwie dwie afordancje odniesione do ludzi o różnym nastawieniu do norm (w obu przypadkach jakoś je uwzględniającym) zachowania się $\mathrm{w}$ miejscu publicznym?

Oba przykłady normatywnego zaangażowania artefaktów uświadamiają, jak skomplikowana jest architektura niszy kulturowych, w których można identyfikować normatywność. 


\section{NORMATYWNOŚĆ A INŻYNIERIA POZNAWCZA}

Niezależnie od wagi włączania aspektu społecznego do prób ekologicznego ujęcia normatywności, przytaczane dotychczas analizy sprowadzały problem do odkrywania afordancji, korzystania z zastanych itp., a przy tym ignorowały sam mechanizm afordancji. Tymczasem afordancje (czy też relacje afordancyjne) możemy kreować oraz znacząco je modyfikować, w dużej mierze dzięki zapoznaniu się z ich strukturą i techniczną stroną funkcjonowania. Dlatego dokonam tutaj ważnego pod tym względem uzupełnienia.

Kategoria afordancji niemal niezależnie zrobiła równoległą „karierę" w teoriach i praktyce wzornictwa przemysłowego, projektowania interakcji człowiek-urządzenia, jak również innych pokrewnych dziedzinach. Wprowadził ją w te obszary kognitywista i teoretyk dizajnu, Donald Norman. Odnosi on tę kategorię do postrzeganych i realnych własności rzeczy, przede wszystkim tych, które decydują, jak dana rzecz mogłaby zostać użyta ${ }^{34}$. Ponieważ propozycję Normana można traktować jako w pełni konkurencyjną wobec Gibsonowskiej koncepcję afordancji, warto porównać podejścia obu badaczy. W najogólniejszym ujęciu różnica zasadza się na tym, że Gibson analizuje afordancje zastane, podczas gdy Norman - możliwości projektowania nowych i ulepszania starych ${ }^{35}$. Istotna różnica dotyczy preferowanych teorii percepcji: pierwszy zakłada jej bezpośredniość, niezapośredniczoną reprezentacjami umysłowymi, lecz opartą na wykrywaniu niezmienników w zmiennych warunkach świetlnych wokół podmiotu; drugi natomiast nie eliminuje reprezentacji z procesu poznawczego, a do afordancji dodaje - a właściwie wydziela z nich - jeszcze sposób ich postrzegania (jak pokażę, nie jest to taka bezwzględna różnica w odniesieniu do roli afordancji). Zauważa się, że dla Gibsona afordancje istnieją niezależnie od historii

34 D. Norman, The Psychology of Everyday Things, New York 2013, 9.

35 Por. np. J. Gibson, dz. cyt.; D. Norman, The Psychology of Everyday Things, dz. cyt. 
aktywności danego podmiotu, podczas gdy dla Normana łączą się z dotychczasową wiedzą i doświadczeniem ${ }^{36}$ - co, jak widzimy, lepiej przystaje do współczesnych koncepcji afordancji kulturowych. Należy także pamiętać, że Norman rozróżnia afordancje realne oraz (tylko) postrzegane, co istotne jest dla naszego posługiwania się artefaktami ${ }^{37}$, jak również wykazuje ważną rolę emocji, w tym nieświadomych, w jednostkowych oraz społecznych interakcjach z otoczeniem, podkreślając znaczenie emocji dla myślenia, podejmowania decyzji, oceny itd. - wskutek czego nie ma obecnie mowy o projektowaniu artefaktów bez uwzględniania aspektu emocjonalnego ${ }^{38}$.

Co więc łączy pod wspólnym mianem afordancje gibsonowskie i normanowskie, postrzegane niereprezentacyjnie i reprezentacyjnie? Łączy je pewien skrót poznawczy: ustrukturyzowane względem nas otoczenie naprowadza nas, podsuwając obiekt w jakiejś wyraźnej mierze zdatny do użycia - w sposób intuicyjny, oczywisty czy po prostu łatwy.

Wątek swoistej inżynierii afordancji prowadzi do kwestii samych mechanizmów i struktur afordancyjnych. Podczas gdy wcześniej Warren badał możliwości optymalizacji afordancji (schody), Gaver rozróżnia i analizuje cztery przypadki ich jawności i realności: (1) afordancje postrzegane, które dzieli na (1.1) jawne (towarzyszy im informacja percepcyjna) oraz (1.2) fałszywe (mimo informacji percepcyjnej brak możliwości działania), a także (2) afordancje niepostrzegane, do których zalicza (2.1) afordancje ukryte (możliwości działania przy braku percepcyjnej informacji) i (2.2) poprawne odrzucenie możliwości działania (brak afordancji oraz percepcyjnej informacji). Ogólnie biorąc, dany artefakt jest łatwy w użyciu, gdy jego afordancje są zgodne $z$ jego przeznaczeniem; $w$ innym przypadku

36 J. McGrenere, W. Ho, Affordances: Clarifying and Evolving a Concept, w: The Proceedings of Graphics Interface, red. S.S. Fels, P. Poulin, Montréal 2000, 181.

37 Np. D. Norman, Affordance, conventions, and design, Interactions 6(1999)3, 38-42.

38 D. Norman, Wzornictwo i emocje. Dlaczego kochamy lub nienawidzimy rzeczy powszednie, tłum. z ang. D. Skalska-Stefańska, Warszawa 2015. 
podsuwa nam inne działania niż te, do których go zaprojektowano ${ }^{39}$. Dobrze z tym koresponduja prace Jonathana Maiera i Georgesa Fadela nad metodami projektowania opartymi na afordancjach: projektanci powinni skupiać się nie tylko na uzyskaniu i optymalizacji pożądanych, pozytywnych afordancji $\mathrm{w}$ danym artefakcie, ale też na unikaniu niechcianych afordancji negatywnych, szkodliwych, mogących pojawić się mimo ich woli (jak to bywa w projektowaniu nastawionym wyłącznie na funkcjonalność ${ }^{40}$.

Czy wiedza ta wnosi dodatkowe światło w problematykę ekologicznie ujmowanej normatywności? Jest to wiedza, która daje twórcom artefaktów społecznych (przemysłowych) pewną władzę i jednocześnie obejmuje ich odpowiedzialnością. Szeroko rozumiana dziedzina dizajnu - bo uwzględniamy tutaj wzornictwo przemysłowe, projektowanie interfejsów, pojazdów, architekturę itd. - to kontrolowana przestrzeń systematycznej optymalizacji życia społecznego (jednostkowego również), a przy tym też otwarte pole badań nad poznaniem i użytkowością. Twierdzenie, jakoby czyniła ona $z$ ludzi biernych i homogenizowanych użytkowników zdanych na cudze wybory, jest mocno nieuprawnione. Oczywiście, projektanci niekiedy błądzą, a efekty interakcji człowiek-urządzenia miewają negatywne skutki uboczne - dość wymienić tutaj wadliwe, nieintuicyjnie otwierane drzwi czy też zjawisko bezmyślnego oglądania programów telewizyjnych, na co wielokrotnie zwraca uwagę Norman. Ten sam autor jednak broni rozwoju techniki skoncentrowanej na człowieku, wzmacniającej, a nie osłabiającej jego możliwości i spektrum wyboru ${ }^{41}$.

39 W. Gaver, Technology affordances, w: Proceedings of the ACM CHI, red. S.P. Robertson, G.M. Olson, J.S. Olson, New Orleans 1991, 79-81.

40 J. Maier, G. Fadel, Affordance based design: a relational theory for design, Research in Engineering 20(2009)1, 22.

41 D. Norman, The Psychology of Everyday Things, dz. cyt., 1-36; D. Norman, Things That Make Us Smart, New York 1994, 3-18. 
Z powyższych względów rola projektantów artefaktów w kształtowaniu „przesyconych” normatywnością nisz kulturowych jest niezwykle istotna. Niejednokrotnie jesteśmy w naszych praktykach normatywnych tak bardzo zdani na wykorzystanie materialnych zasobów otoczenia, że stają się one nieodzowną infrastrukturą realizowania norm; osadzenie zaś ich w afordancjach umożliwia uniknięcie sztywnego podążania za regułami. Afordancje takie, świadomie wpisane w projekt, powinny uwzględniać i coraz częściej uwzględniają nie tylko wymogi bezpieczeństwa czy wygodę, ale też kulturowe konwencje czy lokalne przyzwyczajenia. Wiąże się to do pewnego stopnia ze współdzieleniem odpowiedzialności z artefaktami, a pośrednio tez $-\mathrm{z}$ ich projektantami i wytwórcami. Na ile możemy nabrać zaufania do oferowanych nam artefaktów i technik? Na tyle, na ile pokładamy je w ludziach za nimi stojących, ale też - na ile transparentne są zasady ich działania i sposób użycia (czego nie należy utożsamiać z zaopatrywaniem każdego przedmiotu i miejsca w szczegółowe instrukcje obsługi, choć to skądinąd jest obowiązkiem sprzedawcy czy administratora).

Projektant gwarantuje osiągnięcie danego efektu oraz uniknięcie niepowodzenia, jeśli używamy danego artefaktu zgodnie z przeznaczeniem. Sam obiekt natomiast, jeżeli został dobrze wykonany, niejako sam sobą demonstruje zasadę działania i granice bezpiecznego użycia. Takiej gwarancji ani demonstracji nie dostarczają nam twory natury użyte w charakterze narzędzia; tutaj to my, decydując się na ich użycie, ponosimy pełną odpowiedzialność, zwłaszcza jeśli wykorzystujemy je na potrzeby innych. Przy wytwarzanych przemysłowo artefaktach - jest ona społecznie rozłożona.

Nosze medyczne, dobrze wykonane, certyfikowane, nie powinny się rozlecieć ani kogoś uszkodzić, nawet jeśli nie mamy dużej wprawy w posługiwaniu się nimi, gdyż ich części nienadające się do chwytania czy kontaktu z ciałem umieszczono poza zasięgiem użytkowników, w przeciwieństwie do części gwarantujących stabilny uchwyt i bezpieczne przeniesienie poszkodowanego. Tego już nie można 
zawsze powiedzieć o noszach wykonanych z konieczności amatorsko i naprędce z przypadkowych elementów. Czy to oznacza, że profesjonalnych noszy użyjemy bezmyślnie, a prowizorycznych - odpowiedzialnie? Nie, to oznacza, że tych pierwszych prawdopodobnie będzie nam łatwiej użyć, a ponadto ktoś (producent) podzielił się z nami odpowiedzialnością za ich wykorzystanie zgodne z przeznaczeniem.

Dizajn wprowadza świadomie i odpowiedzialnie „rzeczy społeczne”. Jeżeli więc jakieś artefakty określać jako „klej społeczny” dla danej wspólnoty ${ }^{42}$, to pewne artefakty byłyby takim klejem dla normatywnej architektury danej niszy kulturowej. Wdrażane, ulepszane, służą optymalizacji relacji między podmiotem a powinnością. Co ważne, perspektywa ta nie wymyka się etycznemu ujęciu normatywności: wpasowuje się w zakres tak zwanej etyki dalekiego zasięgu $^{43}$, która w dużej mierze dzięki nowoczesnej technice umożliwia globalną orientację, organizację i działanie z bardzo lokalnej, wręcz marginalnej perspektywy. Korzystając z interfejsów, sieci, mediów społecznościowych, zyskujemy możliwości (a tym samym odpowiedzialność) wpływania na elementy świata odległe od nas nie tylko przestrzennie. $\mathrm{W}$ ten sposób nasz lokalny, pierwotnie słaby „impuls wrażliwości” możemy transmitować za pomocą ekologicznej translacji technologicznej. Oczywiście, przy takiej skali i ciągu zapośredniczeń wykorzystane afordancje mogą być już tylko normanowskimi afordancjami postrzeganymi, które nie skutkują bezpośrednim kontaktem $\mathrm{z}$ innymi ludźmi. Tym bardziej jednak zacieśnia to społeczną odpowiedzialność i normatywną strukturę naszych ekosystemów kulturowych.

42 Ł. Afeltowicz, Modele, artefakty, kolektywy, Toruń 2012, 340-341.

43 Zob. np. K. Abriszewski, Wszystko otwarte na nowo, Toruń 2010, 162-167; H. Jonas, Zasada odpowiedzialności: etyka dla cywilizacji technologicznej, tłum. M. Klimowicz, Kraków 1996. 


\section{PODSUMOWANIE}

Celem artykułu było wstępne pokazanie z perspektywy ekologicznego nurtu kognitywistyki, jak normatywność usytuowana jest poznawczo w ludzkim otoczeniu rozumianym jako kompleks fizyczno-biologiczno-kulturowy. Założeniem było, że nadaje się do tego koncepcja afordancji, jako łagodząca dualizm podmiot-otoczenie i tym samym akcentująca aktywny udział podmiotu w strukturze jego niszy ekologicznej. Jak się okazuje, trudno odnosić normy do klasycznie rozumianych afordancji (dotyczących jednoznacznych i wyizolowanych relacji między podmiotem a przedmiotem), jak również trudno abstrahować od relacji społecznych. Dlatego też większe przekonanie budzi odniesienie normatywności do afordancji kulturowych, a przy tym również do dziedziny świadomego ich kreowania i modyfikowania. Z tego też względu łatwiej jest mówić o praktykach normatywnych w danych niszach kulturowych.

Czy normy można potraktować jak rodzaj afordancji? Jak próbowałem wstępnie pokazać, praktycznie żadnej wyizolowanej afordancji nie można jednoznacznie przypisać takiej roli. Sprawę dodatkowo komplikuje fakt, że równolegle funkcjonują dwa rozumienia afordancji: jako własności relacyjnej i jako relacji (z tego powodu zaproponowałem używanie - tam, gdzie to możliwe - określenia „relacja afordancyjna”). Uważam, że afordancja może mieć charakter normatywny wyłącznie w kontekście określonej niszy kulturowej - co, być może, jest bardzo skromnym twierdzeniem, sformułowanym w obliczu nadmiernego skomplikowania poznawczo-społecznych relacji podmiotu z otoczeniem. Niemniej, pociąga ono za sobą wymóg identyfikowania afordancji kulturowych w określonym systemie normatywnym, a więc poszerzenie perspektywy badacza. Ponadto takie złożone i nielinearne ujmowanie związków między afordancjami a normatywnością pozwala uniknąć posądzenia o sugerowanie automatyzmu reagowania na afordancję, niezależnie od możliwości błędu percepcyjnego. 
Jeżeli chodzi o możliwe dalsze badania w tym zakresie, interesujące wydaje się przeanalizowanie praktyk normatywnych w kontekście wytworów dizajnu, a więc artefaktów wytwarzanych na masową skalę, poddanych standaryzacji, których użycie związane jest $\mathrm{z}$ rozłożeniem i jednocześnie zacieśnieniem społecznej odpowiedzialności.

Praca koncentruje się na afordancjach obiektów materialnych, zwłaszcza artefaktów, należy jednak pamiętać, że również w kontekście afordancji ciał mamy do czynienia $\mathrm{z}$ wymierną fizycznością (czego nie wolno traktować jako urzeczowienia osoby, tym bardziej że nawet obiekty nieożywione postrzega się tutaj z uwagi na ich zanurzenie w znaczącym ludzkim świecie).

\section{BIBLIOGRAFIA}

Abriszewski K., Wszystko otwarte na nowo, Wyd. UMK, Toruń 2010. Afeltowicz Ł., Modele, artefakty, kolektywy, Wyd. UMK, Toruń 2012. Audi R., Natura normatywności oraz projekt naturalizacji poję́ normatywnych, w: W świecie powinności, red. B. Brożek, M. Hohol, Ł. Kurek, J. Stelmach, Copernicus Center Press, Kraków 2013, 37-78.

Bicchieri C., Muldoon R., Social Norms, w: Stanford Encyclopedia of Philosophy (2011), https://plato.stanford.edu (dostęp: 17.03.2017).

Chemero A., Radical embodied cognitive science, MIT Press, Cambridge 2009. Costantini M., Sinigaglia C., Grasping affordance: a window onto social cognition, w: Joint attention: New developments, red. A. Seemann, MIT Press, Cambridge 2012, 431-459.

Costall A., Afordancje kanoniczne w kontekście, tłum. z ang. K. Bielecka, Avant 3(2012)2, 296-304.

Costall A., Richards A., Canonical Affordances: The Psychology of Everyday Things, w: The Oxford Handbook of the Archaeology of the Contemporary World, red. P. Graves-Brown, R. Harrison, A. Piccini, OUP, Oxford 2013, 82-91.

Dotov D., Nie L., de Wit M.M., Zrozumieć afordancje, tłum. z ang. D. Lubiszewski, N. Strehlau, Avant 3(2012)2, 282-295.

Edmonds D., Eidinow J., Pogrzebacz Wittgensteina, tłum. z ang. L. Niedzielski, Muza, Warszawa 2002.

Ferri F., Campione G.C., dalla Volta R., Gianelli C., Gentilucci M., Social Requests and Social Affordances, PLoS ONE 6(2011)1, e15855, 1-9. 
Gaver W., Technology affordances, w: Proceedings of the ACM CHI, red. S.P. Robertson, G.M. Olson, J.S. Olson, ACM Press, New Orleans 1991, 79-84.

Gibson J., The Ecological Approach to Visual Perception, Psychology Press, New York 2014.

Heft H., An ecological approach to psychology, Review of General Psychology 17(2013)2, 162-167.

Heras-Escribano M., de Pinedo M., Are affordances normative?, Phenomenology and the Cognitive Sciences (2016)15, 565-589.

Hutchins E., Cognition in the wild, MIT Press, Cambridge 1995.

Hutchins E., Cognitive Ecology, Topics in Cognitive Science 2(2010)4, 707-712.

Hutchins E., The cultural ecosystem of human cognition, Philosophical Psychology 27(2014)1, 34-49.

Jonas H., Zasada odpowiedzialności: etyka dla cywilizacji technologicznej, tłum. M. Klimowicz, Wyd. Platan, Kraków 1984/1996.

Lo Presti P., An ecological approach to normativity, Adaptive Behavior 24(2016)1, 3-17.

Maier J., Fadel G., Affordance based design: a relational theory for design, Research in Engineering 20(2009)1, 13-27.

McGrenere J., Ho W., Affordances: Clarifying and Evolving a Concept, w: The Proceedings of Graphics Interface, red. S.S. Fels, P. Poulin, Canadian Information Processing Society, Montreal 2000, 179-186.

Norman D., The Psychology of Everyday Things, Basic Books, New York 2013.

Norman D., Things That Make Us Smart, Basic Books, New York 1994.

Norman D., Affordance, conventions, and design, Interactions 6(1999)3, 38-42.

Norman D. Wzornictwo i emocje. Dlaczego kochamy lub nienawidzimy rzeczy powszednie, tłum. z ang. D. Skalska-Stefańska, Wyd. Arkady, Warszawa 2015.

Papineau D., Naturalism, w: Stanford Encyclopedia of Philosophy (2015), https:// plato.stanford.edu (dostęp: 18.03.2017).

Ramstead M., Veissière S., Kirmayer L., Cultural Affordances: Scaffolding Local Worlds Through Shared Intentionality and Regimes of Attention, Frontiers in Psychology 7(2016), art. 1090, 2.

Rączaszek-Leonardi J., Nomikou I., Rohlfing K., Young children's dialogical actions, IEEE Transactions on Autonomous Mental Development 5(2013)3, 210-221.

Rietveld E., Kiverstein J., A rich landscape of affordances, Ecological Psychology 26(2014)4, 325-352.

Turvey M., Affordances and prospective control: An outline of the ontology, Ecological Psychology 4(1992)3, 173-187. 
Warren W., Perceiving affordances: visual guidance of stair climbing, Journal of Experimental Psychology 10(1984)5, 683-703.

Warren W., Wang S., Visual guidance of walking through apertures, Journal of Experimental Psychology (1987)13, 371-383.

\title{
SITUATED NORMATIVITY. AN ECOLOGICAL ACCOUNT
}

\begin{abstract}
This article discusses the extent to which normativity is situated in human biological and cultural ecosystems, with an emphasis on the role of artefacts. The basic question addressed is whether affordances - however defined - may be normative. The text briefly introduces cognitive ecology and ecological psychology, and then moves on to consider and reject the possibility of applying classical affordance theory to normativity. Lastly, it attempts to modify this account by referring to social and cultural affordance. The review and its conclusions are complemented by an original proposal to advance research on the normativity of affordances through an analysis of their structures and by stressing the role of human-artefact interaction.
\end{abstract}

Keywords: norm; affordance; cognition; perception; ecology; culture; artefact

Artykuł zrealizowano w ramach grantu Narodowego Centrum Nauki PRELUDIUM 8 (decyzja nr 2014/15/N/HS1/03994).

WITOLD WACHOWSKI

wwachowski@ifispan.waw.pl

Instytut Filozofii i Socjologii PAN

Nowy Świat 72, 00-330 Warszawa

Uniwersytet Warszawski, Instytut Filozofii

DOI:10.21697/spch.2018.54.1.16 